\title{
IMPACT OF CORPORATE IAMGE ON THE USE OF BANK SERVICE: A CASE OF CONVENTIONAL vS. ISLAMIC BANKS MARKETING
}

\author{
M. Ishaq Bhatti ${ }^{1}$ \\ Hayat Muhammad Awan, and Ahmed Nabeel Siddiquei ${ }^{2}$
}

\begin{abstract}
This paper compares Bank's corporate image on customer's satisfaction to enhance marketability between Islamic (IB) and conventional banks $(C B)$ in Pakistan. A sample of 320 customers is selected from four major cities of the country to ask about brand image, firm's reputation, ethics and corporate social responsibility (CSR). It is observed that the word-of-mouth, firm's reputation and security are the main drivers for CB's whereas for the IB's, the brand familiarity, reputation, CSR and bank's communication and Shariah compliancy. Quantitative methodology is used to analyze the collected data. It is proposed that the management of these banks should make efforts to implement these findings to enhance both types of banking services in the country to best satisfaction of their clients.
\end{abstract}

Keywords: Marketing; Corporate image; Islamic banks; Analytical; Hierarchical Process; Shariah Finance

\section{Introduction}

Over the last decade, deregulation and technology breakthroughs have obliged financial companies to face increasing competition and re-consider their marketing strategies (O'Loughlin and Szmigin, 2005). The financial services today faces new challenges, derived from the spread of new technologies and the greater intensity of competition exercised by new channels for doing business. The situation today is more competitive than ever due to the financial crisis that has been wreaking havoc in international markets ${ }^{3}$. Moreover, studies of previous financial crises paint a gloomy scenario as credit supply commonly does not recover for two to- three years after a crisis hits (Bhatti and Nguyen 2012, World Economic Prospects, 2009). When it comes to Islamic Finance $^{4}$, financial services, customers usually have difficulties in evaluating competing offerings. Because of service intangibility, financial institutions must develop powerful Image as a Corporate that reduce the perceived risk of consumers and provide an alternative for differentiation (de Chernatony and Cottam, 2006).

In this context, corporate image must be considered as a valuable strategic tool that could ease long-term success. Corporate image are an organization's identity encompasses a bundle of values that are derived from a federation of subcultures, which are found within and outside the organization (Balmer and Wilson, 1998). We may consider that corporate image is a strategic tool of great value for the financial sector, since besides helping to achieve long-term objectives (Awan et al 2015, Abratt and Mofokeng, 2001) it can turn into a source of competitive advantage. This is due to the fact that corporate image is one of the most difficult resources to imitate, as a consequence of the extensive time period that is needed to develop it (Hall, 1993). In addition to

\footnotetext{
${ }^{1}$ La Trobe University, Melbourne, Australia, Email: i.bhatti@latrobe.edu.au, Phone: +61 394792715

${ }^{2}$ Department of Business Administration, Air University, Multan Campus, E-mail: hma@aumc.edu.pk

${ }^{3}$ A good source of information about principles of Islamic markets are available in Abd Rahman et al (2015), Mansor et al. (2015), Jamal and Sharifuddin, J. (2015), Hong and Chang (2015) and Mastura et al. (2016) among others.

${ }^{4}$ An excellent information on the subject matter is given by Kettel (2010) and Khan and Bhatti (2008). For a discussion of behavioral and operational differences in the light of modern economic theory, see Basov and Bhatti (2016). Basov and Bhatti $(2013,2014)$ studied the effects of trust-related psychological costs on the structure of optimal contracts between parties under Shariah contracts.
} 
image, attitude of customers toward a brand, or Brand Attitude, is another key component for valuing a corporate equity. Mitchell and Olson (1981) define Brand Attitude as an individual's overall evaluation of a brand. This means that attitude toward a brand mainly depends on a consumer's own perceptions regarding a brand, and are argued to be a reliable predictor of consumers' behavior toward brands (Shimp, 2010). Most researchers (e.g. Keller and Aaker, 1993; Faircloth et al., 2001; Helgeson and Supphellen, 2004) regard these two as distinctive concepts where corporate image helps develop potential buyers' overall evaluation or attitude toward a brand.

Previous researches in this field suggest that consumers organize a cluster of attributes and create an image association related to the corporation around both functional and symbolic dimensions (Park et al., 1986). A variety of studies have made it clear that corporate image and consumer attitude towards a brand can significantly affect individual behavior (e.g. Ratnasingham, 1998). The attitudinal dimension describes a consumer's overall satisfaction with the corporation and the tendency of a consumer to purchase a particular brand repeatedly over time with the same corporation. Some previous studies (Wu and Lo, 2009) find a positive relationship between brand attitude and purchase intention toward a brand. A similar relationship appears to exist between a corporate's brand image and loyalty toward the brand. Researchers such as Keller (1993) view purchase loyalty toward a corporation as an outcome of effectively managing knowledge about a corporate image and attitude towards the corporation. Therefore, both a corporate image and the buyers' attitude toward a brand contribute to purchase intention towards the brand (Faircloth et al., 2001).

From above, we conclude that the image perceived by the consumer helps to make tangible the influential factors present at the moment of execution of a financial transaction, diminishing the risk perceived by the individual and simultaneously increasing the purchase intention. Despite the importance that researchers have assigned to the variables of corporate image and attitude in the distribution of financial services, we consider that much of the work so far is in the initial phase of development especially in financial service sector. This fact is reflected especially when relating image to other variables that might influence decision-making of consumers especially the purchase intention. In this respect, we stress the work that has analyzed the relationship between corporate image, attitude and purchase intention. Thus, the majority of the works concerning the corporate image/attitude relationship have been approached from a fundamentally theoretical perspective (e.g. Lehu, 2007), or else the empirical testing has been carried out in an indirect way, based on factors that form part of the image or are related to it, such as, for example, reputation or perceived usefulness (Bahia and Nantel, 2000).

Consequently, today we have no research in financial service sector that has empirically evaluated the role played by corporate image in the formation of brand attitude and consumer's purchase intention pertaining to financial services. Similarly, the influence of this attitude on purchase intention has not been evaluated. Therefore, this paper carries out a study of the relationship between corporate image on Brand attitude and Purchase Intention and the mediating role of brand attitude in financial services. It is restricted to the corporate image of the banking sector only in a specific region of the world. Other aspects of the banking sector may have been ignored by giving preference to the image only. To our knowledge, this is the first study that makes a comparison between Islamic and conventional banks' corporate image and to determine the key drivers for both types of banks separately.

Finally, major conclusions will be drawn based on statistical analysis and principal managerial implications will be presented. Section 2 discusses the literature review and section 3 explain the methodology used in this study. Whereas the section 4 presents the result and section 5 gives the discussion and the managerial implication of the study. 


\section{Literature Review \\ Corporate Brand Image}

According to Bravo et al (2009) the brand image represents the perceptions reflected as existing associations in the mind of customers. The corporate image can be considered as a name of organization rather individual product in the mind of customer. From the organizational perspective, corporate image is conceptualized as the way in which an organization's members believe external stakeholders perceive their organization (Dutton et al., 1994) or the way that an organization's managers would like outsiders to view their company (Whetten et al., 1992). In both cases, corporate image is the internal construction of public impressions. The views of customers, shareholders, the media, the general public, and any other external stakeholders are the basis of image (Hatch and Schultz,2003). Nevertheless, it is usual in the marketing literature to focus on customers and it is accepted that corporate image represents the beliefs, attitudes, impressions and associations held by customers about a corporation (Belt and Paolillo, 1982; Keller, 1993).

Indeed many authors postulate that a corporate image is the most effective means for differentiation in banking (Richardson and Robinson 1986, Van Heerden and Puth, 1995). In this context, image has become main management tool for banking industry (Worcester, 1997) and an extremely complex construct that calls for increasing number of elements for its analysis (Balmer and Stotvig, 1997; Biel 1992; Keller 1993, LeBlanc and Nguyen 1996; Nguyen and LeBlanc, 1998; Park et al. 1986; Van Riel et. al, 2001; Worcester, 2009).

The study of corporate image includes many factors as Keller (1993) postulated that it is comprised of all attributes, benefits and attitudes towards a brand. Corporate image gathers all the perceptions that stakeholders can have of the firm. Thus, corporate image becomes a multidimensional construct formed by all the impressions and expectations that individuals develop throughout a certain period of time (Howcroft, 1991). Mandel et al (1981) organize the dimensions of analysis in relation to customer benefit, bank benefit, bank descriptor and progressiveness. LeBlank and Nguyen (1996) pointed to relevance of studying the reputation of directors, services offering,, contact personnel, corporate identity, access to service and physical environment. Souiden et al (2006) included CSR in addition to some other dimensions which was also acknowledged as one of the most important factors in determining corporate reputation (Worcester, 2009). While a strong corporate reputation can provide a competitive advantage (Balmer, 2001), stakeholders are becoming skeptical about firms' reasons for engaging in CSR (Vlachos et al., 2009), making it more difficult for researchers and practitioners to understand the specific consequences and effects of engaging in CSR activities (Maignan and Ralston, 2002). Bravo et al (2010) very comprehensively and parsimoniously developed a scale of corporate image in terms of five dimensions like global image, service offering, personnel, location and CSR for the commercial banks based on the past different studies.

Several authors focused on the effect of various features of service offered, personnel and reputation among other associations on the decision of customer to use the bank service (Kaynak and Whiteley,1999 Bravo et al ,2009, 2012). The details of these dimensions are listed as:

\section{Global impression}

General impression transmitted by banks on its customers has previously been considered as a dimension of corporate image in various studies (e.g. van Heerden and Puth, 1995; O'Cass and Grace, 2004); O'Loughlin and Szmigin, 2005). Howcroft (1991) defines it as 'the sum total of impressions and expectations acquired by customers and non-customers alike over a period of time'. An impression of trust transmitted by a bank and its associated entities has a significant impact on the customer's perception regarding the bank. (Yavas and Shemwell, 1996; Bahia and Nantel, 2000; Flavia'n et al., 2005; da Silva and Faridah, 2006). Latest study from Bravo et al. (2009) found global impression as one of the dimension of corporate image. They found bank's promise fulfillment, honesty, friendliness and inspiration of confidence as the measurement 
variables of this impression. The dimension of global impression is also comparable with those of visual identity (van Heerden \& Puth, 1995). They emphasized branch attractiveness, stylish servicescape and modern looks as the identity building factors of banks. Additionally, name of the bank, its logo, kind of customers, and affiliation with union movement also has an impact on this visual identity which ultimately influences corporate image (LeBlanc and Nguyen, 1996).

\section{Service Offering}

Service offering has been widely considered as a dimension of bank's corporate image (Bravo et al., 2009). Various authors have found that the service offerings and their quality is a critical element in the development of corporate image. LeBlanc and Nguyen (1996) considered services offering as a dimension of corporate image. They found variety of loans and savings, service technology and loans policy as important variables of service offering that measures corporate image. Study from Karatepe, Yavas and Babakus (2005) points to service environment, quality of service interaction, empathy and reliability of services offerings as facets of corporate image. Variables of service offering in terms of quantity and attractiveness of service, interests (received and paid) on service products and commissions charged by the banks are significant to measure bank's corporate image (Flavia'n et al., 2005). Reliability in service offering is a critical factor that determines customer's perception of corporate image (e.g. Yavas et al., 2004; da Silva and Faridah, 2006; Loonam and O'Loughlin, 2006). Personalized services and products offered by a bank has a positive significant effect on corporate image (Aldlaigan and Buttle, 2002; Flavia'n et al. , 2005; Arasli et al.,2005; Karatepe et al. ,2005). With the introduction of internet and selfservice technology in banking, the dimension of service offering is measured by innovative and modern services offered by them (Bahia and Nantel, 2000; O'Loughlin and Szmigin, 2005; Souiden et al., 2006). As a result of the same the transactional security as a variable of service offering has also been given preference by customers to develop their perception of corporate image (Bahia and Nantel, 2000; Yavas et al., 2004; Flavia'n et al., 2005). Few authors have also explored that the dimension of service offering is composed of several financial variables like interests received/paid on loans and commissions charged by banks (Mandel et al., 1981; Kaynak and Whiteley, 1999; Flavia'n et al. ,2005; Yavas and Shemwell ,1996; Mandel et al. ,1981; Kaynak and Whiteley ,1999; Flavia'n et al. ,2005).

\section{Personnel}

The value of a corporate brand is grounded in the values and affinities of company founders, owners, management and personnel. Personnel as a dimension of corporate image have been discussed by previous authors using multiple variables. Corporate image of a bank depends on the kindness and friendly nature of the staff, personnel professionalism and availability (van Heerden and Puth, 1995; Parasuraman et al.,1988; Aldlaigan and Buttle, 2002, Flavia'n et al., 2005; Yavas et al., 2004; Karatepe et al., 2005). Knowledge of the contact personnel tends to impart trust on customer regarding bank and its services offering (LeBlanc and Nguyen, 1996). Study from Bravo et al. (2009) also found staff professionalism, appearance, friendly nature and customer orientation to be essential variables of this dimension. Similarly, professionalism, kindness of the personnel, friendliness and the trustworthiness of the entire company has also been considered by (Flavia'n et al., 2004). Additionally, O'Cass and Grace (2004) determined interpersonal service in the form of Courteous, timely service, competency, quick assistance and customer treatment as the corporate image builders of financial service organizations.

\section{Location}

Location of a bank's branch is considered as one of the key dimension of corporate image (Bravo et al., 2009). This dimension has been measured by number of branches of a bank, luxuriousness, size of various branches (Mandel et al., 1981). Consumers prefer a bank that has a 
convenient location and is accessible for them (Flavia'n et al., 2005). Study from (Bravo et al., 2009) found that the corporate image of a bank rest on its locality in addition to the number of branches and easy accessibility. Convenient and nearby location is significant dimension of a bank's corporate image (Evans, 1979). While studying corporate image of financial institutions Bravo et al. (2012) explored location as one of the key dimension of corporate image. There is a strong consensus, particularly amongst the large multinationals, that architecture and location are an important aspect of corporate image (Karaosmanoglu and Melewar, 2006). Latest study of Bravo et al. (2009) concerning scale development and validation found location as one of important dimension of corporate brand image in retail banking.

\section{Corporate social responsibility}

CSR has only lately been recognized as one of the most key elements in identifying business popularity (Worcester, 2009). Variables like community benefit, environmental respect and commitment with society forms the corporate social responsibility dimension of corporate image (Bravo et al., 2009). Research has found hyperlinks between CSR and business identification, CSR has been involved in quality designs affecting company popularity and business picture (Cornelius et al., 2007). More companies than ever are trying to make use of CSR organizations, with CSR reviews "filling websites and brochures" (Snider et al., 2003). Kay (2006) highlights the importance of tying corporate brands to their corporate social responsibility practices. Cause-related campaigns are frequently implemented to promote a socially responsible image (Keller and Richey, 2006), which positively differentiates them from competitors (Karaosmanoglu and Melewar, 2006; Kay, 2006) and heightens the company evaluation (Brown et al., 2005). Castelo and Lima (2006) categorize corporate social responsibility information provided by banks in four areas: environmental, human resources, products and consumers and community involvement disclosures. In this work, product quality, charitable donations, support for education, arts and culture are the most frequent information provided in companies' websites. The corporate social responsibility dimension includes the investment in charitable giving, ecological stewardships and, in general, benefits to society (Castelo \& Lima, 2006; Souiden et al., 2006). Similarly bank's dedicating resources for the welfare of locality (da Silva and Faridah, 2006; Stubbs and Cocklin, 2007, Ali et al. 2016 and Ali and Park 2016); respecting and addressing environmental concerns (Bouma and Klinkers, 2001) tend to develop a positive corporate image. To sum up, it can be concluded that the analysis of the corporate image in commercial banking may adopt many different perspectives.

\section{Effect of associations of corporate Image on consumer behavior}

The consumers having a positive image in mind of a company will be seen in their global attitude toward the company. Some authors prove that corporate associations and global reputation of a company are the factors that affect positively the assessment of the products (Madrigal,2000; Souiden et al., 2006; Brown et al.,2005). Devlin and Azhar (2004) say that trust and reassurance feelings are crucial factors providing differentiation and generating positive consumer responses in relation to financial services brands. Hence we propose the following hypothesis based on the model depicted in fig. 1. 


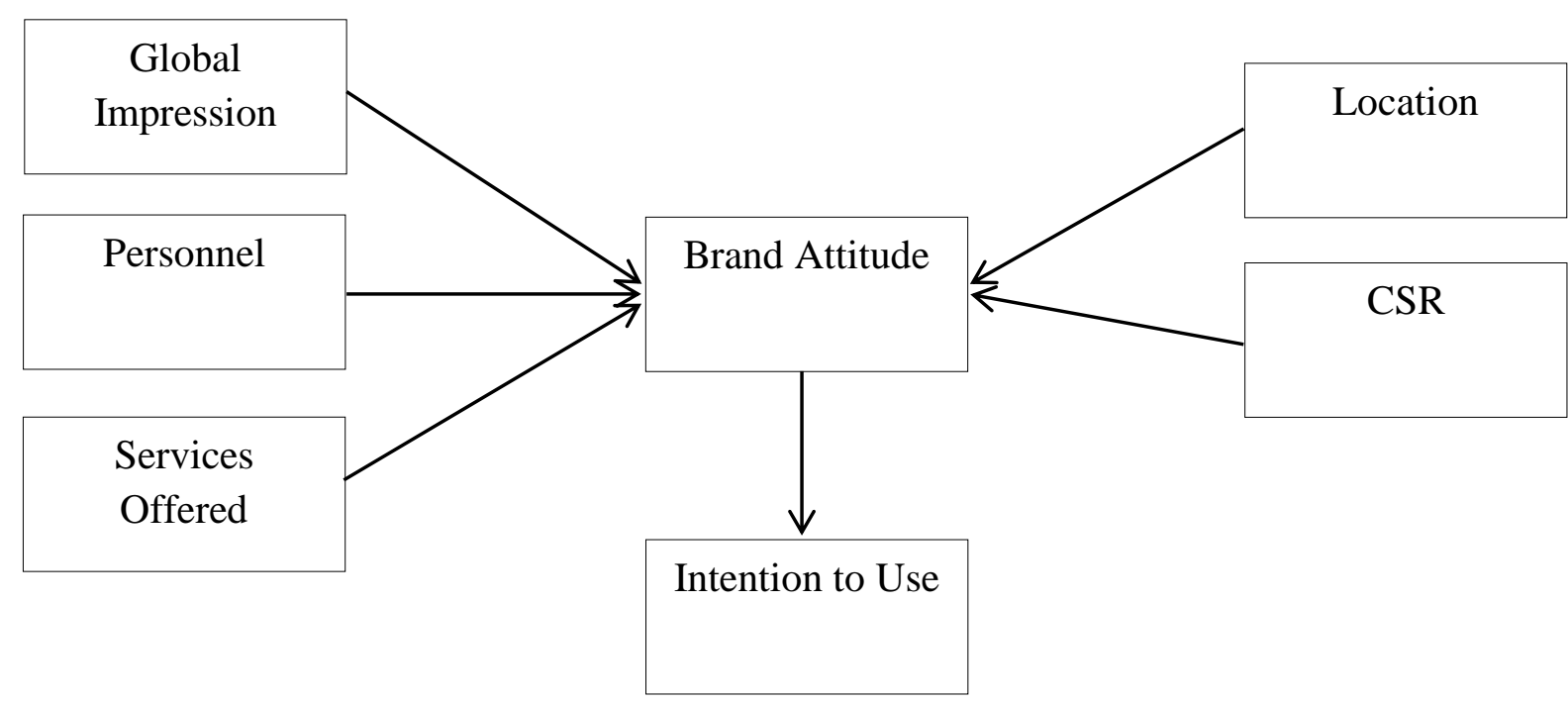

Figure 1

H1: The associations of corporate Image like global impression, services offered, Personnel, Location and CSR have positive effect on service brand attitude for Conventional and Islamic banks.

The behavior intentions are expected to depend on individual's attitude which will depend, in turn, on brand beliefs (Fishbein and Ajzen, 1975).Wu and Lu., 2009 verified that perceptions about a brand influence the attitude toward the brand name, which influence the purchase intentions. Specific corporate association such as service perception may directly affect the buying intentions (Gounaris and Stathakopoulos., 2004). The service quality literature reveals that customer's perceptions enhance behavoural intentions and loyality toward service companies (Yavas et al., 2004). On the basis of this we propose the following hypotheses

H2: The service brand attitude has a direct positive effect on intention to use the services of commercial and Islamic banks

H3: The service brand attitude mediate the effect of different dimensions of corporate image like global impression, services offered, personnel, location and CSR on intention to use the services of commercial and Islamic banks (Indirect effect of dimensions of corporate image is positive on intention to use the services).

\section{Methodology}

An experimental survey was conducted among the customers of conventional and Islamic banks in four big cities- Multan, Faisalabad, Lahore, and Islamabad. 400 customers were selected (200 each in Islamic and Conventional banks). The sample was systematically selected with every 10th customer entering in the bank. We selected those conventional banks that were specialized in the same portfolio without having any window of Islamic banking and vice versa.

\section{Research instrument and data collection}

Structured questionnaire is used as a data collection instrument. Data was collected by handing over the printed questionnaires to the respondents (Bank customers) in four cities \& get the filled questionnaire collected at the same time. These questionnaires are filled out by bank customers of different professional backgrounds e.g. Job holders, Businessmen's. Questionnaire includes components of corporate image as discussed in literature review in detail, particularly by Btavo et al (2010) such as services offered, location, global impression, personnel and CSR. These dimensions and factors are given in Figure -1. Questionnaires comprised of 17 items of these dimensions and 7 and 6 items of brand attitude and intention to use service respectively. All these items were measured over a likert scale of 1 to 7 . Questionnaires are pre-tested to ensure, understandability and clarity to the respondents in making the comparison of different questions 
pairwise of all dimensions discussed above. The scale for measurement of this comparison is used as -9 to 9 suggested by Wind and Saaty (1980). Open ended questions were asked about the demographics like age, gender, education level, city, occupation, type of bank, years using the specific type of bank's services. The exploratory factor analysis was used on the pretest data, which confirm the dimensionality. The reliability and validity of scales is confirmed through the confirmatory factor analysis.

The AHP technique is used to identify the critical factors of the corporate image and the correlation and structural equation model is used to confirm whether the data support the hypotheses or not. All these analysis are conducted separately for the conventional and Islamic banks data.

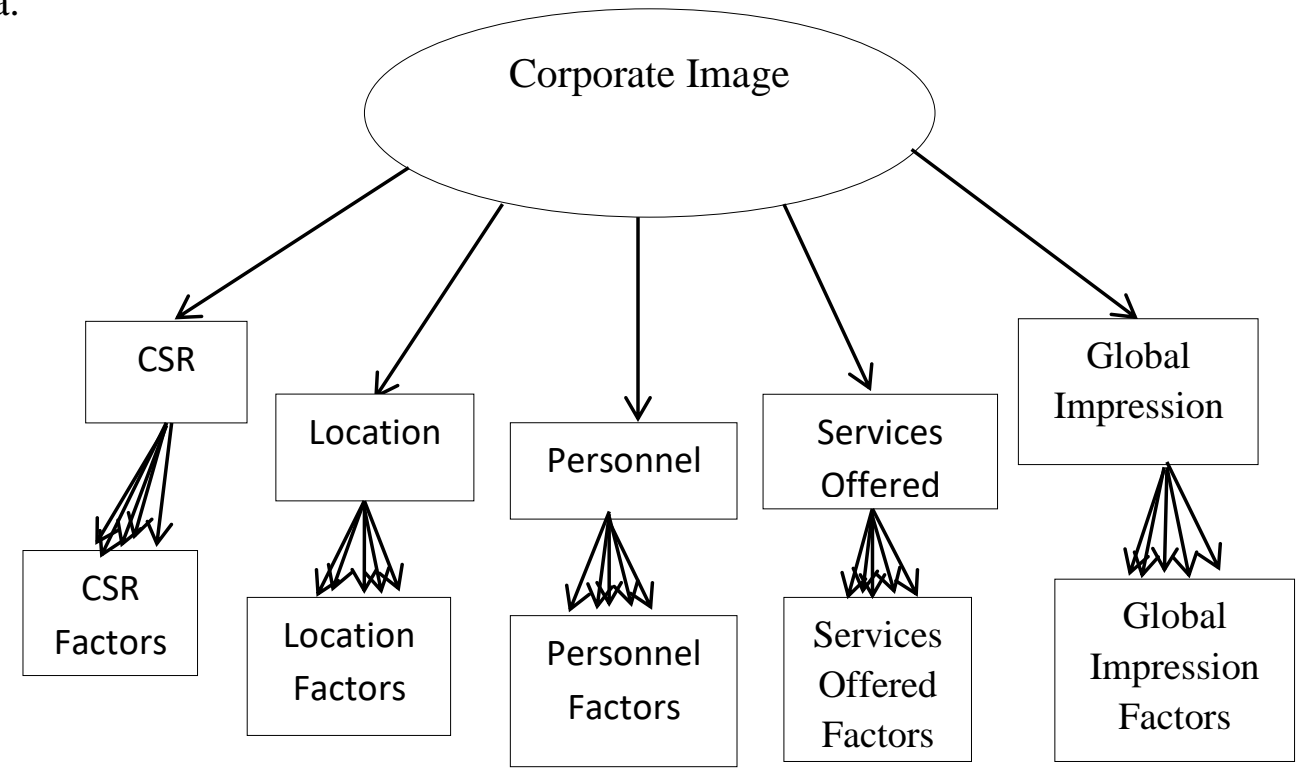

Figure 2: Proposed Model

\section{Data analysis}

\section{Analytical Hierarchical Process}

Wind and Saaty (1980) introduced AHP, in which the qualitative measures are converted into vector scale weights that are pooled into linear addition weights for alternatives. These resultant weights are used to prioritize the alternatives and thus the decision maker would be in a better position to make a proper decision (Formen and Gass, 2001). The corporate image is composed of five sub constructs as already explained in the literature review. Those sub constructs are portrayed in Fig.1. A detailed analysis is done in order to develop a hierarchical index based on global priority weights of indicators of corporate image which indicates the relative importance towards selecting these indicators for conventional and Islamic banks.

\section{Global Weights for Conventional Banks.}

Data in Table -I show results of AHP. The tier I consist of four critical factors. Critical factors are those factors which have a very high impact in determining the corporate image for the bank in customer's perspective. First critical item: The bank is honest. Second critical item: The bank makes a good impression on you. Third critical item: The personnel's appearance is adequate and the fourth critical item: Bank's personnel are highly professional. These four critical factors have the global priority weights of $0.0036,0.0039,0.0046$ and 0.0052 respectively. These four critical factors come under the constructs of "Global Impression" and "Personnel" respectively. This means that these two factors are of greater importance for the customers in making or breaking their perception of the image about the bank, the conventional banks need to make a well global impression and professionally trained personnel. So in case of conventional banks it can be 
understood that one of the top priority for the customers of conventional banks is good impression of bank. The finding is consistent with the findings of (Bravo et al (2009). Since the third and the fourth critical factors for the conventional banks are personnel. The investment in recruiting and training of personnel professionally will ultimately improve the corporate image of conventional banks.

\section{Analytical Hierarchy Associations of Corporate Image for}

\begin{tabular}{|lr|}
\hline The bank gives back to the communities in which it does business & 0.195659 \\
The bank supports good causes. & 0.185289 \\
The bank staff is always at its customer's disposal. & 0.174587 \\
The bank has environmental friendly policy and objectives & 0.072153 \\
Branches of this bank are close to my home/workplace & 0.05994 \\
The bank inspires confidence. & 0.059243 \\
The bank offers an ample variety of products and services & 0.056506 \\
This bank is a well-established entity in the locality. & 0.048858 \\
This bank has a high number of branches. & 0.042941 \\
Services offered by this entity are reliable. & 0.041259 \\
The bank always fulfills its promises. & 0.040126 \\
In general, bank staff is friendly and warm. & 0.039155 \\
The bank is a friendly entity. & 0.03759 \\
Bank personnel's are highly professional. & 0.005215 \\
The personnel's appearance is adequate. & 0.00459 \\
The bank makes a good impression on you. & 0.003897 \\
The bank is honest & 0.003589 \\
\hline
\end{tabular}

\section{CONVENTIONAL BANKS}

The tier II consists of five factors which support the critical factors. First supporting item: The bank is a friendly entity. Second supporting item: In general, bank staff is friendly and warm. Third supporting item: The bank always fulfills its promises. Fourth supporting item: Services offered by this entity are reliable. Fifth supporting item: This bank has a high number of branches. These five supporting factors have the global priority weights of $0.0376,0.0392,0.0401,0.0413$ and 0.0429 respectively. These five supporting factors come under the constructs of Global Impression, personnel and services offered. Among these five supporting factors, two factors belong to "Global Impression" and one each to "personnel, services offered and location". Well trained and professional sound personnel build a good impression of the bank as well as the corporate image. Therefore the investment in this regard will pay to the management.

The tier III consists of the eight items representing the maintaining factors which are 
generally exercised by the different kinds of conventional banks in the country. These factors have their own role in the progress of corporate image but they are not critical for image building process of the banks. Conventional Banks should not spend plenty of resources on these items too. However, if they are concerned for improvement then it is appreciated. They are not necessary to be focused or improvement in them will have a very mild effect. The items with respect to their global weights for maintaining factors can be shown in the tier III column.

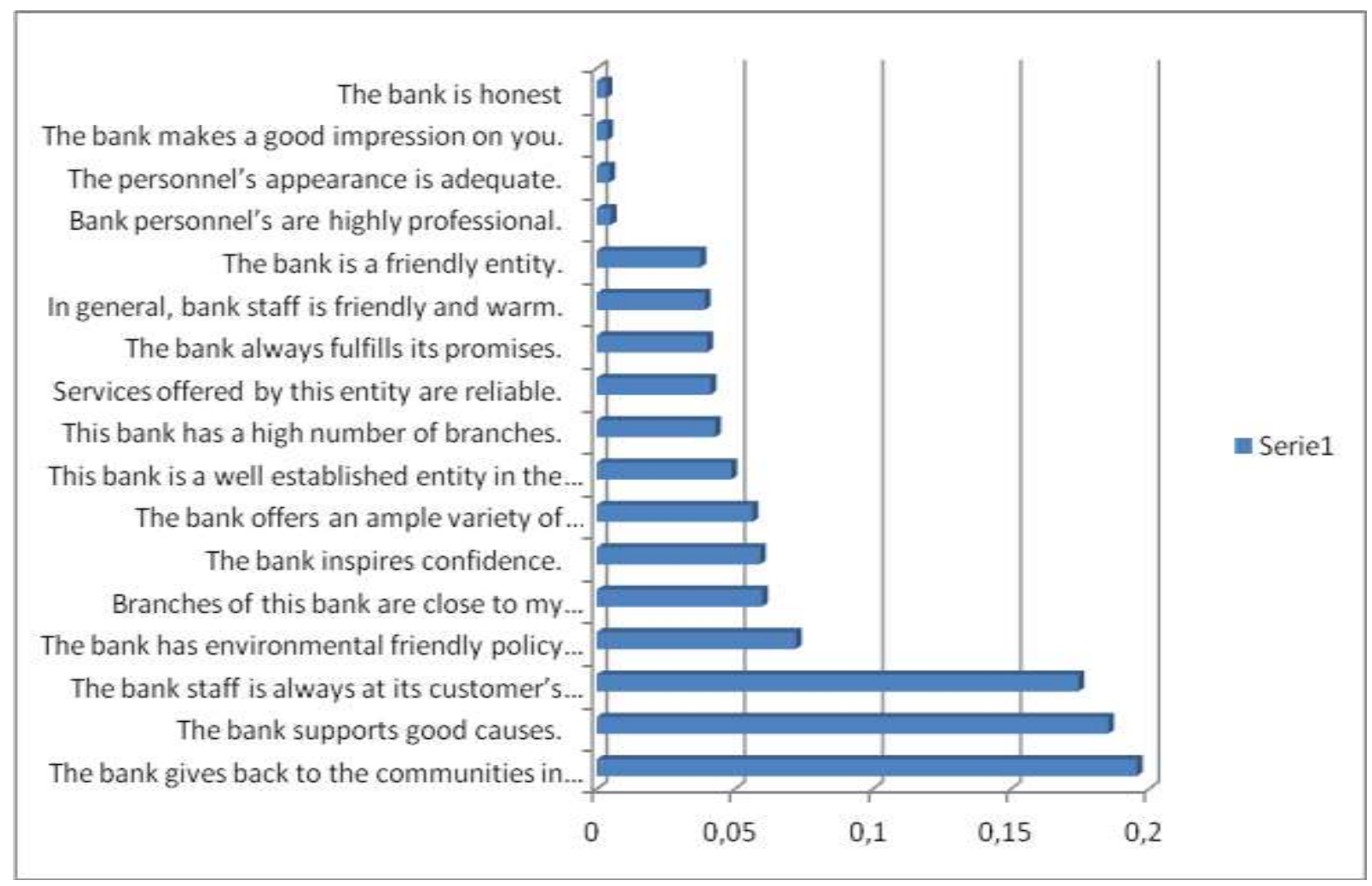

Global weights for Islamic Banks:

Data in Table-II shows result of AHP in Islamic banking sector along with the global priority weights of 17 factors of corporate image. The tier I consists of five critical factors. Critical factors are those factors which have a very high impact in determining the corporate image for the bank in customer's perspective. First critical item: The bank inspires confidence. Second critical item: The bank always fulfills its promises. Third critical item: Services offered by this entity are reliable. Fourth critical item: Branches of this bank are close to my home/workplace and the fifth critical item: This bank is well established entity in the locality. These five critical factors have the global priority weights of $0.0489,0.0059,0.0060,0.0061$ and 0.0061 respectively. These five critical factors lies under the constructs of "Global Impression" "Services offered" and "Location" respectively. The management of Islamic banks should dedicate their resources towards these dimensions. The customers of Islamic banks are not well aware with the services being offered by Islamic banks which are in compliance with Shariah, therefore the management of Islamic banks not only build their global impression rather make the investment in making the customers aware with the services offered. Because of enormous competition in banking sector of Pakistan (Islamic and Conventional) customers prefer to deal with the bank offering superior services. Therefore, it would be safe to say that the Islamic banks should spend in Service quality management and services in compliance with Shariah. 


\section{ISLAMIC BANKS}

\begin{tabular}{|lr|}
\hline The bank gives back to the communities in which it does business & 0.171013 \\
This bank has a high number of branches. & 0.170261 \\
The personnel's appearance is adequate. & 0.166251 \\
The bank supports good causes. & 0.072501 \\
The bank offers an ample variety of products and services & 0.072028 \\
In general, bank staff is friendly and warm. & 0.066599 \\
Bank personnel's are highly professional. & 0.064045 \\
The bank has environmental friendly policy and objectives & 0.056264 \\
The bank makes a good impression on you. & 0.048379 \\
The bank staff is always at its customer's disposal. & 0.04686 \\
The bank is a friendly entity. & 0.039548 \\
The bank is honest & 0.038756 \\
This bank is a well-established entity in the locality. & 0.006135 \\
Branches of this bank are close to my home/workplace & 0.006124 \\
Services offered by this entity are reliable. & 0.005963 \\
The bank always fulfills its promises. & 0.005879 \\
The bank inspires confidence. & 0.004885 \\
\hline
\end{tabular}

The tier II consists of four factors which support the critical factors. First supporting item: The bank is honest. Second supporting item: The bank is a friendly entity. Third supporting item: The bank staff is always at its customer's disposal. Fourth supporting item: The bank makes a good impression on you. The global priority weights for these four factors are $0.0388,0.0395,0.0468$, and 0.0484 respectively. These four supporting factors lie under the constructs of global impression and personnel. Among these four supporting factors, first, second and fourth item belong to global impression whereas the third item belong to personnel This means that to support the factors of critical importance on the image building process for the Islamic bank's customers the management should investment on the personnel to support critical factors.

The tier III consists of the 8 items representing the maintaining factors which are generally exercised by the different kinds of Islamic banks in the country. Islamic Banks should not spend plenty of resources on these items too. However, if they are concerned for improvement then it is appreciated. The improvements in these factors will have a very mild effect. The items with respect to their global weights for maintaining factors can be shown in the tier III. 


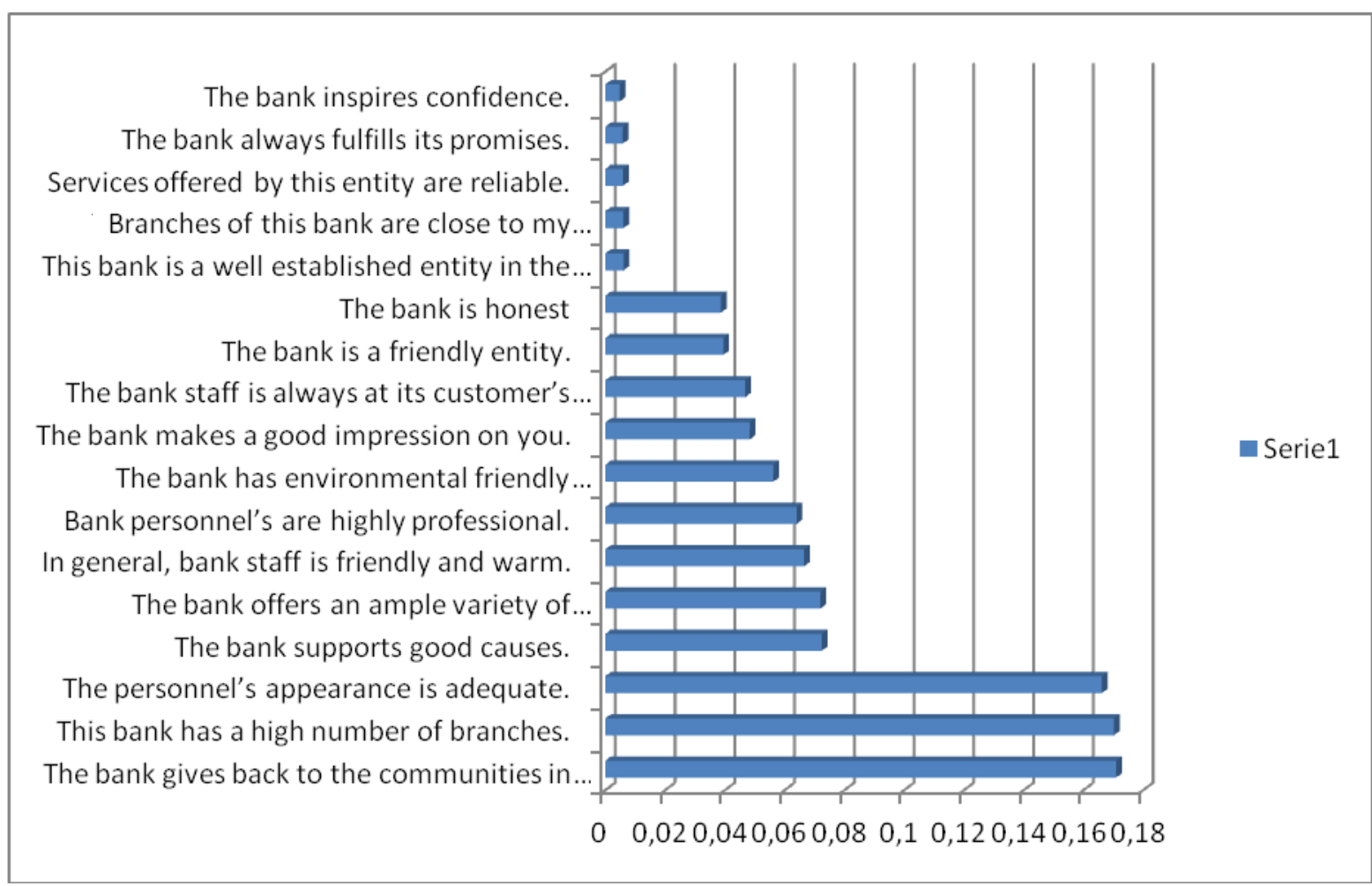

\section{Overall AHP Comparison}

Finally the AHP results show that while considering the factors of critical importance, both the conventional as well as Islamic bank customers put emphasis on global impression While the customers for the conventional banks give more importance to the personnel. On the other side customers of Islamic banks are more concerned with the services offered and location of the bank.

Comparison Table

Table III

\begin{tabular}{|c|c|c|}
\hline \multicolumn{3}{|c|}{ Global Priority Weights (Critical Factors Only) } \\
\hline Ranks & Conventional Banks & Islamic Banks \\
\hline 1 & $\begin{array}{l}\text { The bank is honest. } \\
\text { (Global Impression) }\end{array}$ & $\begin{array}{l}\text { The bank inspires confidence } \\
\text { (Global Impression) }\end{array}$ \\
\hline 2 & $\begin{array}{l}\text { The bank makes a good impression on you } \\
\text { (Global Impression) }\end{array}$ & $\begin{array}{l}\text { The bank always fulfills its } \\
\text { promises. } \\
\text { (Global Impression) }\end{array}$ \\
\hline 3 & $\begin{array}{l}\text { The personnel's appearance is adequate } \\
\text { (Personnel) }\end{array}$ & $\begin{array}{l}\text { Services offered by this entity are } \\
\text { reliable (Services offered) }\end{array}$ \\
\hline 4 & $\begin{array}{l}\text { Bank's personnel are highly professional } \\
\text { (Personnel) }\end{array}$ & $\begin{array}{l}\text { Branches of this bank are close to } \\
\text { my home/workplace } \\
\text { (Location) }\end{array}$ \\
\hline
\end{tabular}




\section{Correlation}

The correlation analysis is applied to check the impact of various components of corporate image indices on each other and the overall image index to know how these are facilitating each other in developing the corporate image and in which direction, which is also used to answer the second research question. The Pearson correlation coefficients (R) are listed in table VI.

\section{Conventional Banks}

The correlation analysis for conventional banks show that the most important correlated factor towards corporate image is "global impression" $(\mathrm{R}=0.909, \mathrm{p}=.000)$. Whereas it also has highly significant and positive relationship with personnel $(\mathrm{R}=0.732, \mathrm{p}=.000)$, service offering $(\mathrm{R}=0.579, \mathrm{p}=0.000)$, location $(\mathrm{R}=0.544, \mathrm{p}=0.000)$, and CSR $(\mathrm{R}=0.321, \mathrm{p}=.000)$. It confirms that all the components of CI improve the global impression which ultimately becomes the main determinant that could help in the improvement of the corporate image of the firm.

Table IV (a)

\section{Corelations coefficient of corporate association for Conventional Banks}

\begin{tabular}{|c|c|c|c|c|c|c|c|}
\hline \multicolumn{8}{|c|}{ Correlations } \\
\hline & & W_GI & W_Servc & W_Location & W_per & W_Csr & W_CI \\
\hline \multirow[t]{3}{*}{ W_GI } & Pearson Correlation & 1 & $.579^{* *}$ & $.544^{* *}$ & $.732^{* * *}$ & $.321^{* * *}$ & $.909^{* * *}$ \\
\hline & Sig. (2-tailed) & & .000 & .000 & .000 & .000 & .000 \\
\hline & $\mathrm{N}$ & 160 & 160 & 160 & 160 & 160 & 160 \\
\hline \multirow[t]{3}{*}{ W_Servc } & Pearson Correlation & $.579^{* * *}$ & 1 & $.543^{* *}$ & $.578^{\text {*** }}$ & $.356^{* *}$ & $.747^{\text {*** }}$ \\
\hline & Sig. (2-tailed) & .000 & & .000 & .000 & .000 & .000 \\
\hline & $\mathrm{N}$ & 160 & 160 & 160 & 160 & 160 & 160 \\
\hline \multirow[t]{3}{*}{ W_Location } & Pearson Correlation & $.544^{* * *}$ & $.543^{* *}$ & 1 & $.541^{* * *}$ & $.410^{* * *}$ & $.806^{* * *}$ \\
\hline & Sig. (2-tailed) & .000 & .000 & & .000 & .000 & .000 \\
\hline & $\mathrm{N}$ & 160 & 160 & 160 & 160 & 160 & 160 \\
\hline \multirow[t]{3}{*}{ W_per } & Pearson Correlation & $.732^{* * *}$ & $.578^{* * *}$ & $.541^{* * * *}$ & 1 & $.291^{* * *}$ & $.814^{* * *}$ \\
\hline & Sig. (2-tailed) & .000 & .000 & .000 & & .000 & .000 \\
\hline & $\mathrm{N}$ & 160 & 160 & 160 & 160 & 160 & 160 \\
\hline \multirow[t]{3}{*}{ W_Csr } & Pearson Correlation & $.321^{* *}$ & $.356^{* *}$ & $.410^{* * *}$ & $.291^{* * *}$ & 1 & $.458^{* *}$ \\
\hline & Sig. (2-tailed) & .000 & .000 & .000 & .000 & & .000 \\
\hline & $\mathrm{N}$ & 160 & 160 & 160 & 160 & 160 & 160 \\
\hline \multirow[t]{3}{*}{ W_CI } & Pearson Correlation & $.909^{* *}$ & $.747^{* *}$ & $.806^{* * *}$ & $.814^{* * *}$ & $.458^{* * *}$ & 1 \\
\hline & Sig. (2-tailed) & .000 & .000 & .000 & .000 & .000 & \\
\hline & $\mathrm{N}$ & 160 & 160 & 160 & 160 & 160 & 160 \\
\hline
\end{tabular}

**. Correlation is significant at the 0.01 level (2-tailed).

The second highest contributor in terms of correlation strength towards the corporate image is the "personnel" having $(\mathrm{R}=0.814, \mathrm{p}=.000)$ and it has also significantly positive relationship with service offering $(\mathrm{R}=0.578, \mathrm{p}=0.000)$, location $(0.541, \mathrm{p}=0.000)$ and $\mathrm{CSR}(\mathrm{R}=0.291, \mathrm{P}=.000)$. Above all the stated factors are controllable factors for the banks. Therefore the efforts to enhance these factors would enhance the personnel and consequently corporate image.

The third most contributor in terms of correlational strength is location $(\mathrm{R}=0.806, \mathrm{P}=000)$ and it has significant positive relationship with service offering $(\mathrm{R}=0.543, \mathrm{p}=.000)$ and $\mathrm{CSR}(\mathrm{R}=0.410$, 
$\mathrm{p}=.000)$. The fourth and fifth contributors are service offering $(\mathrm{R}=0.747, \mathrm{p}=.000)$ and CSR $(\mathrm{R}=0.458, \mathrm{p}=.000)$.

\section{Islamic Banks}

The correlation analysis for Islamic banks show that the first factor in order of correlation strength is "Global Impression" which is highly significant and positively contributing ( $\mathrm{R}=0893$, $\mathrm{p}=0.000$ ) towards corporate image. It is also positively related with personnel, service offering, CSR, and location which clearly indicates that the efforts for enhancement of these factors will lead to improved global impression. It will ultimately enhance the level of corporate image. The second factor in order of correlation strength is "service offering" $(\mathrm{R}=0.727, \mathrm{p}=0.000)$ with corporate image. It also has highly significant and positive relationship with CSR and location. The investment in CSR and location will increase the service offering of firm, which will eventually enhance the corporate image of the bank.

Table IV (b)

Corelations coefficient of corporate association for Islamic Banks

\begin{tabular}{|c|c|c|c|c|c|c|c|}
\hline \multicolumn{8}{|c|}{ Correlations } \\
\hline & & W_GI & W_servc & W_Location & W_per & W_Csr & W_CI \\
\hline \multirow[t]{3}{*}{ W_Gl } & Pearson Correlation & 1 & $.464^{* *}$ & $.333^{* * *}$ & $.550^{* * *}$ & $.345^{\text {*** }}$ & $.893^{* * *}$ \\
\hline & Sig. (2-tailed) & & .000 & .000 & .000 & .000 & .000 \\
\hline & $\mathrm{N}$ & 160 & 160 & 159 & 160 & 160 & 159 \\
\hline \multirow[t]{3}{*}{ W_servc } & Pearson Correlation & $.464^{* *}$ & 1 & $.350^{* *}$ & $.190^{*}$ & $.406^{* * *}$ & $.727^{* *}$ \\
\hline & Sig. (2-tailed) & .000 & & .000 & .016 & .000 & .000 \\
\hline & $\mathrm{N}$ & 160 & 160 & 159 & 160 & 160 & 159 \\
\hline \multirow[t]{3}{*}{ W_Location } & Pearson Correlation & $.333^{* *}$ & $.350^{* * *}$ & 1 & $.251^{* * *}$ & .043 & $.579^{* *}$ \\
\hline & Sig. (2-tailed) & .000 & .000 & & .001 & .592 & .000 \\
\hline & $\mathrm{N}$ & 159 & 159 & 159 & 159 & 159 & 159 \\
\hline \multirow[t]{3}{*}{ W_per } & Pearson Correlation & $.550^{* *}$ & $.190^{*}$ & $.251^{\text {*** }}$ & 1 & $.260^{* * *}$ & $.613^{* *}$ \\
\hline & Sig. (2-tailed) & .000 & .016 & .001 & & .001 & .000 \\
\hline & $\mathrm{N}$ & 160 & 160 & 159 & 160 & 160 & 159 \\
\hline \multirow[t]{3}{*}{ W_Csr } & Pearson Correlation & $.345^{* *}$ & $.406^{* *}$ & .043 & $.260^{* * *}$ & 1 & $.443^{* *}$ \\
\hline & Sig. (2-tailed) & .000 & .000 & .592 & .001 & & .000 \\
\hline & $\mathrm{N}$ & 160 & 160 & 159 & 160 & 160 & 159 \\
\hline \multirow[t]{3}{*}{ W_Cl } & Pearson Correlation & $.893^{* *}$ & $.727^{* * *}$ & $.579^{* * *}$ & $.613^{* * *}$ & $.443^{* *}$ & 1 \\
\hline & Sig. (2-tailed) & .000 & .000 & .000 & .000 & .000 & \\
\hline & $\mathrm{N}$ & 159 & 159 & 159 & 159 & 159 & 159 \\
\hline
\end{tabular}

The third and fourth most correlated factors contributing toward the corporate image is "personnel" and 'location'. Whereas the CSR is the last component contributing toward the corporate image and is posively related with it $(\mathrm{R}=0.443, \mathrm{p}=0.000)$.

\section{Structural Equation Model:}

The analysis of data obtained for both commercial and Islamic banks is conducted by means of structural equations Model to check the hypotheses proposed earlier. 
Given that some authors conclude that corporate associations influence both direct and indirectly, consumers' behavior (Bei and Chiao, 2000). We use competing five models to study the effect of adding the direct relationship between different image factors and intention of use with mediating effect of Brand attitude. Table $\mathrm{V}$ shows how the introduction of such relationship affects the mediating role of brand attitude. As seen in these results, the estimation of these models confirms the existence of differentiation effects according to each type of association. The direct effect of global impression on intention to use the services is $(\beta=0.223, p=0.000)$ highly significant as well maintaining the indirect effect through brand attitude $(p=0.005)$. Similarly personnel $(\beta=0.335, p=0.000)$ appears to be relevant for decision to continue working with a specific commercial bank. Also personnel significantly affect the brand attitude and it also maintains the indirect effect on intention to use the service through brand attitude. The CSR has significant positive influence directly and indirectly on intention to use the service, whereas the service offered and location have no direct effect on intention to use the services but indirectly maintain effect through brand attitude.

Table V

Results of the Competitive Models for the Customers of Conventional Banks

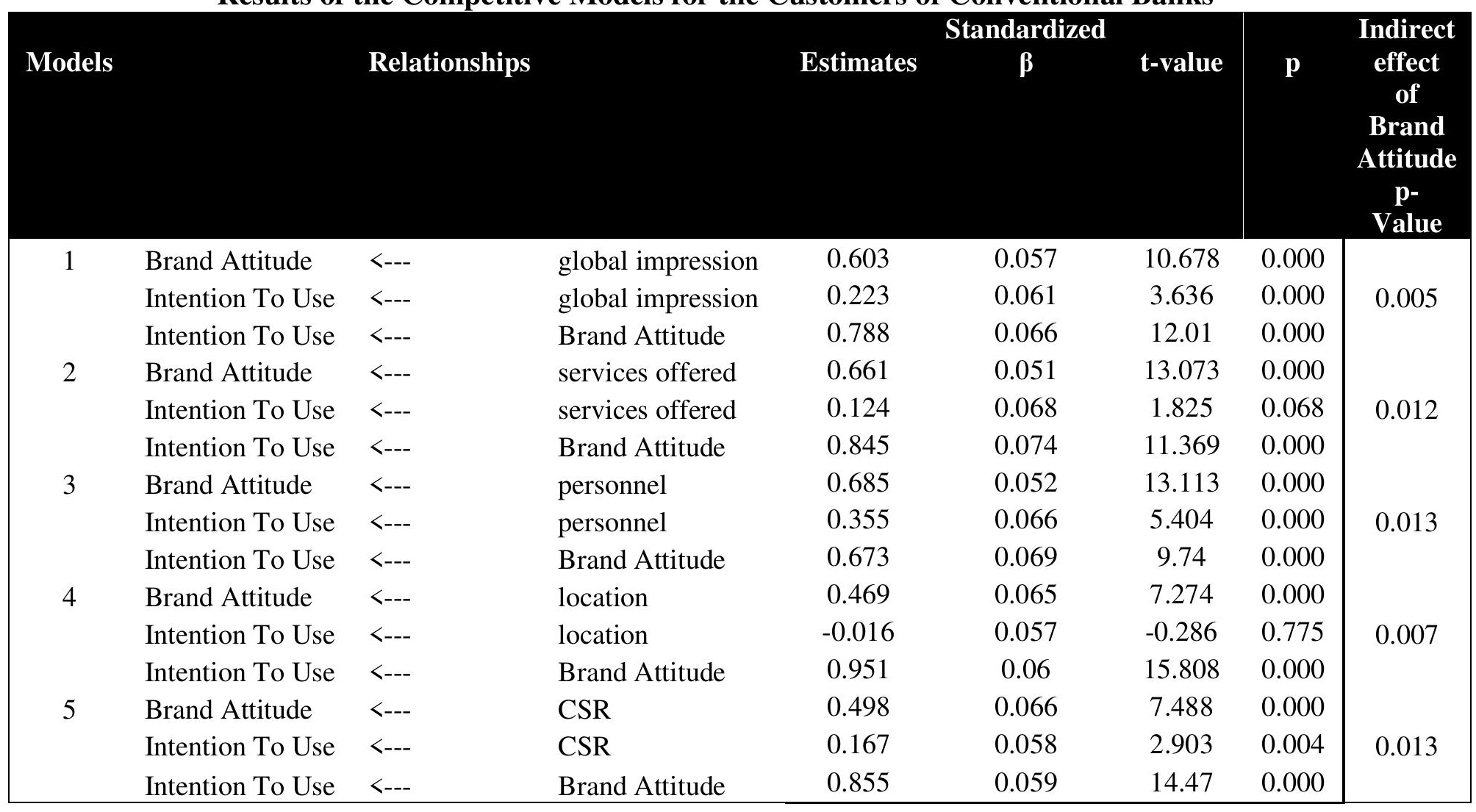

\section{Islamic Bank}

Table VI shows the direct and indirect effect of different corporation image factors on intention to use the Islamic banking service. All corporate associations positively influence the brand attitude with high significance. The global impression of direct effect on intention to use ( $\beta=$ $0.310, \mathrm{p}=0.000$ ) as well as maintaining the indirect effect through brand attitude is significant high. The services offered $\quad(\beta=0.200, p=0.007)$ and location $(\beta=0.149, p=.000)$ appear to be the relevant functions for decision to continue working with a specific Islamic bank. Also services offered and location maintains the indirect effect on intention to use the service through brand attitude. However the personnel has medium direct effect on intention to use the Islamic banking 
services $(\beta=0.166, p=0.03)$. All the associations of corporate image have significant positive indirect effect on intention to use the Islamic banks services through brand attitude.

\section{Results of the competitive models for the customers of Islamic banks}

Table VI

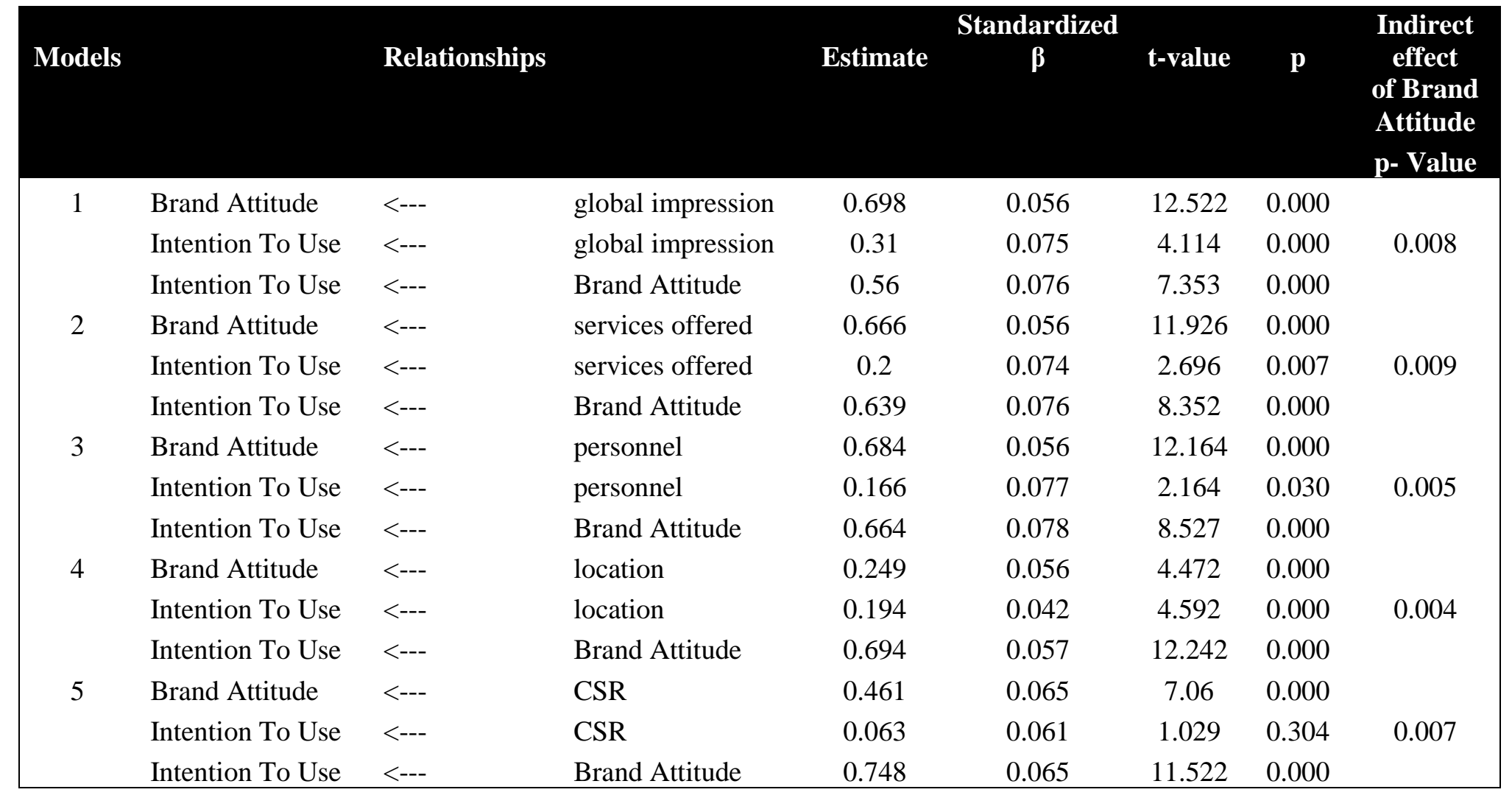

\section{Results and Discussion}

A lot of research was conducted on the contribution of service quality toward the success of commercial banking (Yavas at al 2004; Chen et al 2005), a little attention has been given to the role of specific association of functional and emotional type. Davilin and Azhar (2004) said that the most financial brands enjoy name awareness, although they have no differentiated specific associations in the market place. Therefore it is very natural in the present competitive environment of financial institutions and particularly emergence of Islamic Banking to achieve competitive advantage and customers preferences will be to build a sound corporate image in the customer's mind (Johnson and Wilson 1993; de Chernatony and Cottam, 2006). There is very little knowledge of the effect of specific corporate associations on customer's attitude and purchasing behavior (Bravo et al 2009). This is partly due to the fact that corporate associations of financial institutions as well as importance attached to them vary throughout time (Rodriguez-del-Bosque et al. 1992).

In the present study we develop the corporate brand image based on pool of items of previous studies (Evan, 1979; Stubbs and Coklin, 2007 and particularly the scale of corporate image developed by Bravo et al. (2010). The exploratory and Confirmatory factor analysis confirms the five dimensions, which are serves offered, global impression, personnel, location and CSR composing of 17 items for both conventional and Islamic banks. In this study we have explained how different corporate associations can affect the customers intention to use the services of the company and mediating role of brand attitude.

According to the results, in case of customers of commercial banks, the global impression, personnel and CSR are the dimensions which directly affect the intention to use conventional banking services. The location has no role at all, whereas the services offered to some extent play a 
role in this regard because the conventional banks in Pakistan have a very long history and have very standard services. Some big banks like Habib Bank, UBL etc. sponsor the supports events of cricket and hockey, as well as spend a reasonable amounts on the social causes in terms of scholarship for students etc. Therefore customers are well aware with such activities of CSR. However, customers attach more weight to the Global impression and the personnel.

The customers of Islamic banks give more weights to global impression, services offered and location. These three associations are directly affecting positively the intention to use the banking services. However, the effect of personnel is moderate on intention to use the service, but there is no relationship of CSR. Since the services of Islamic banks were quite newly started, therefore the location of the service matter and no substantial budget for these new banks are allocated for the CSR activities and hence this association has no role in the eyes of customers. We observe that the brand attitude exerts almost uniformly on the relationship between corporate associations and the purchase behavior, as this indirect effect is significant for all the corporate associations for both types of banking system. As for the managerial application, it is obvious from these results that banks have to adopt their marketing strategies in function of the individual's previous experience with their firms. To sustain the business the banks have to develop strong brands with a different corporate image association and provide competitive advantage (O'Loughlin and Szmigin, 2005; de chernatony and Cottam, 2006). All the corporate associations are not equally effective in appealing the customers of conventional and Islamic banks. Marketing or brand managers must consider the peculiarities of the customers of these different types of banks and allocate resources to transmit these associations with higher impact on the building of brand attitude and intention to use the banking services.

The maintaining a customer is less expensive than attracting a new one. Therefore the management of conventional banks should concentrate more on the activities related to building global impression \& CSR, provision of qualified personnel and with little less emphasis on services offered. Whereas in case of Islamic banks more emphasis should be put on the services offered, building of global impression and location. The role of qualified and competent staff in Islamic banks is not as much as that we observed in conventional banks.

\section{Managerial Implications}

The research draws useful implications for corporate managers of two types of banks i.e. Conventional and Islamic. Since previous researches of corporate image has focused on the relationship between corporate image and behavioral outcomes like attitude, loyalty and satisfaction. However, this research has established strong implications by developing relationship between dimensions of corporate image and behavioral outcomes of Attitude and Intention to use.

In conventional banks, corporate image dimensions of service offerings, personnel, CSR, global impression and location has a positive significant impact on customer attitude and intention to use ( direct and indirect). However, the managers of conventional banks should favor the dimension of global impression which is built as a result of resource and strategic investment in service personnel, service offerings, CSR and location. If a bank wants to create a strong corporate image, it must not only rely on the service offerings, CSR and personnel rather the location of the bank is also the critical element in building process.

In Islamic banks, corporate image dimensions of service offerings, personnel, CSR, global impression and location has a positive significant impact on customer attitude and intention to use( direct and indirect). However, the global impression has the highest contribution among all discussed dimensions of corporate image which is influenced by service personnel, service offerings, CSR and location.

It is advisable for bank marketers in Pakistan to favor approaches of societal marketing when they want to create a positive corporate image. Customers do get influenced by responsible activities carried by the banks. Since it is difficult to create competitive advantage of financial 
institutions from service offerings and personnel only therefore adequate attention must be given to the decisions related to location of bank branches. It is interesting to find that except for global impression all dimensions of corporate image are well within bank's control. Therefore, investment in controllable dimensions of service offering, personnel, location and CSR activities as a part of strategy will enhance an overall global impression of a bank.

\section{Limitations and future directions}

The finding of the study raises some questions to be addressed in the future. Firstly, the study is conducted in banking sector of Pakistan and in a specific cultural context. Application of the same model in different service sector and country could yield varying results. Secondly, the respondents of this study were customers of the banks; it would be interesting to acquire the data from other stakeholders of bank.

\section{Acknowledgement}

The initial version of the paper was presented in the $6^{\text {th }}$ Islamic Marketing Conference in Turkey. We're thankful to the conference participants and Dr. Ali for making constructive comments to improve the quality of the paper. The $1^{\text {st }}$ author acknowledges the hospitality of King Abdulaziz University, Saudi Arabia where the final version of the paper is completed.

\section{References}

1. Abd Rahman, A., Asrarhaghighi, E., \& Abd Rahman, S., 2015. Consumers and halal cosmetic products: Knowledge, religiosity, attitude and intention. Journal of Islamic Marketing, 6(1), $148-163$.

2. Abratt, R., Mofokeng, T. N., 2001. Development and management of corporate image in South Africa, European Journal of Marketing, 3/4, 368-386.

3. Ailawadi, K. L., Keller, K. L., 2004. Understanding retail branding: conceptual insights and research priorities, Journal of Retailing, 80(4), 331-42.

4. Aldlaigan, A.H., Buttle, F. A., 2002. SYSTRA-SQ: A new measure of bank service quality, International Journal of Service Industry Management, 13(3/4), 362-382.

5. Ali, M., Park, K. 2016. The mediating role of an innovative culture in the relationship between absorptive capacity and technical and non-technical innovation. Journal of Business Research, 69(5), 1669-1675.

6. Ali, M., Seny Kan, A, K., Sarstedt, M., 2016. Direct and configurational paths of absorptive capacity and organizational innovation to successful organizational performance. Journal of Business Research, forthcoming.

7. Arasli, H., Mehtap-Smadi, S., and Katircioglu, S. T., 2005, Customer service quality in the Greek Cypriot banking industry, Managing Service Quality, 15(1), 41-56.

8. Awan, M.H., Bhatti, M.I., Razaq, Z., 2015. Financial Management: The impact of performance indicators on the organisational profitability, Corporate Governance \& Performance, 13 (1), 84-96.

9. Bahia, K., Nantel, J., 2000. A reliable and valid measurement scale for the perceived service quality of banks, International Journal of Bank Marketing, 18 No. 2, 84-99.

10. Balmer, J. M. T., 2001. From the Pentagon: a new identity framework", Corporate Reputation Review, 4(1), 11-22.

11. Balmer, J. M. T., Greyser, S. A., 2006. Corporate Marketing. Integrating Corporate Identity, Corporate Branding, Corporate Communications, Corporate Image and Corporate Reputation, European Journal of Marketing, 7/8, 730-741.

12. Balmer, J.M.T. and Stotvig, S., 1997. Corporate identity and private banking: a review and case study, International Journal of Bank Marketing, 15(5), 169-84.

13. Bansal, H.S., Voyer, P.A., 2000, Word-of-mouth processes within a services purchase 
decision context, Journal of Service Research, 3(2), 166-77.

14. Basov, S., Bhatti, M. I., 2013. Optimal Contracting Model in a Social Environment and Trust Related Psychological Costs, The BE Journal of Theoretical Economics, 13, 1-14.

15. Basov, S., Bhatti, M. I., 2014. On Sharia' a-Compliance, Positive Assortative Matching, and Return to Investment Banking, Journal of International Financial Markets, Institutions \& Money, 30, 191-195.

16. Basov, S., Bhatti, M. I., 2016. Islamic Finance in Light of Modern Economic Theory, Palgrave, Mac-Millan, in press with publisher.

17. Belt, J.A., Paolillo, J.G.P., 1982. The influence of corporate image and specificity of candidate qualifications on response to recruitment advertisements, Journal of Management, 8, 105-112.

18. Bhatti, M.I., Nguyen, C., 2012. Diversification Evidence from International Equity Markets using Extreme Values and Stochastic Copulas, Journal of International Financial Markets, Institutions \& Money, 22 (3): 622-646.

19. Bhatti M. I. Awan H.M., Razzaq, Z., 2013. The key performance indicators (KPIs) and their impact on overall organizational performances, Journal of Quality and Quantity, 48(6), 31273143.

20. Biel, A. L., 1992. How brand image drives brand equity, Journal of Advertising Research, 32, RC6-RC12.

21. Bouma, M. J., Klinkers, L., 2001. Sustainable banking: The greening of finance. New York: Greenleaf in association with Deloitte and Touche.

22. Bravo, R., Montaner, T., Pina, M. J., 2012. Corporate brand image of financial institutions: a consumer approach, Journal of Product and Brand Management, 21(4) pp. 232 - 245.

23. Bravo, R., Montaner, T., Pina, M. J, 2010. Corporate brand image in retail banking: development and validation of a scale, The Service Industries Journal, 30(8), 1199-1218.

24. Bravo, R, Montaner, T., Pina, M. J., 2009. The role of bank image for customers versus noncustomers, International Journal of Bank Marketing, 27(4), 315-334.

25. Brown, T.J., Barry, T.E., Dacin, P.A., Gunst, R.F., 2005. Spreading the word: antecedents of consumers' positive word-of-mouth intentions and behaviours in a retailing context, Journal of Academy of Marketing Science, 33(2), 123-38.

26. Casalo', L.V., Flavia'n, C., Guinalı'u, M., 2006. Trust: key concept in the development of virtual communities, in Putnik, G.D. and Cunha, M.M. (Eds), Encyclopedia of Networked and Virtual Organizations, Idea Group Reference.

27. Castelo, M., Lima, L., 2006. Communication of corporate social responsibility by Portuguese banks: a legitimacy theory perspective, Corporate Communications, 11(3), 232-48.

28. Cornelius, N., Todres, M., Janjuha-Jivraj, S., Woods, A., Wallace, J., 2007. Corporate social responsibility and the social enterprise, Journal of Business Ethics, 81, 355-70.

29. Crespo, A. H., Rodríguez del Bosque, I., 2005. Influence of corporate social responsibility on loyalty and valuation of services, Journal of Business Ethics, 61(4), 369-385.

30. Daniel, K. T., Nicholas, R., 2013, Determinants of customer loyalty in Kenya: does corporate image play a moderating role?, The TQM Journal, 25(5),473-491.

31. da Silva, R.V., Faridah, S. S. A., 2006. Cognitive, affective attributes and conative, behavioural responses in retail corporate branding, The Journal of Product and Brand Management, 15(5), 293-305.

32. de Chernatony, L., Cottam, S., 2006. Why are all financial services brands not great?, Journal of Product and Brand Management, 5(2), 88-97.

33. Devlin, J. F. , Azhar S., 2004. Life would be easier if we were a Kit Kat: Practitioners' views on the challenges of branding financial services successfully, Journal of Brand Management, 12 No. 1, 12-30.

34. Dutton J. E., Dukerich, J. M., Harquail, C.V., 1994. Organizational images and member identification, Administrative Science Quarterly, 39, 239-63. 
35. Evans, R., 1979. Bank selection: it all depends on the situation, Journal of Bank Research, 9, 242-245.

36. Faircloth, J.B., Capella, L.M., Alford, B.L., 2001. The effect of brand attitude and brand image on brand equity, Journal of Marketing Theory and Practice, 9(3), 61-75.

37. Fishbein, M., Ajzen, I., 1975. Belief, attitude, intention and behavior: An introduction to theory and research. Reading, MA: Addison-Wesley. http://people.umass.edu/aizen/f\&a1975.html.

38. Flavian, C., Guinaliu, M., 2005. The influence of virtual communities on distribution strategies in the internet, International Journal of Retail and Distribution Management, 33(6), 405-25.

39. Gounaris, S., Vlasis S., 2004. Antecedents and consequences of brand loyalty: an empirical study, The Journal of Brand Management, 11(4), 283-306.

40. Hall, R., 1993. A framework linking intangible resources and capabilities to sustainable competitive advantage, Strategic Management Journal, 14, 607-18.

41. Hatch, M. J., Schultz, M., 2003. Bringing the Corporation into Corporate Branding, European Journal of Marketing, 37(7/8), 1041-1064.

42. Helgeson, J. G., Supphellen, M., 2004. A conceptual and measurement comparison of selfcongruity and brand personality-The impact of socially desirable responding, International Journal of Market Research, 46(2), 205-233.

43. Hong, J., Chang, H.H., 2015. I" follow my heart and "we" rely on reasons: The impact of selfconstrual on reliance on feelings versus reasons in decision making, Journal of Consumer Research, 41(6), 1392-1411.

44. Howcroft, J. B., 1991. Customer satisfaction in retail banking, Service Industries Journal, 11(1), 11-17.

45. Jamal, A., Sharifuddin, J., 2015. Perceived value and perceived usefulness of halal labeling: The role of religion and culture. Journal of Business Research, 68(5), 933-941.

46. Karaosmanoglu, E., Melewar, T. C., 2006. Corporate communications, identity and image: A research agenda, Journal of Brand Management, 14(1/2), 196-207.

47. Karatepe, O. M., Yavas, U., Babakus, E., 2005. Measuring service quality of banks: Scale development and validation", Journal of Retailing and Consumer Services, 12, 373-383.

48. Kay, M. J., 2006. Strong brands and corporate brands, European Journal of Marketing, 40(7/8), 742-760.

49. Kaynak, E., Whiteley, A., 1999. Retail bank marketing in Western Australia, The International Journal of Bank Marketing, 17(5), 221-230.

50. Kettell, B., 2010. Islamic Finance in a Nutshell, West Sussex: John Wiley and Sons.

51. Khan, M. M., Bhatti M. I., 2008. Development in Interest free Banking, Palgrave-Macmillan, $\mathrm{UK}$

52. Keaveney, S. M,. 1995. Customer switching behavior in service industries: an exploratory study, Journal of Marketing, 59 No. 2, 71-83.

53. Keller, K. L., Aaker, D. A., 1997. Managing the corporate brand: The effect of corporate marketing activity on consumer evaluations of brand extensions", Working paper report No. 97-106, Cambridge, MA: Marketing Science Institute (http://www.msi.org/publications/ index.cfm)

54. Keller, K. L., 1993. Conceptualizing, measuring, and managing customer-based brand equity, Journal of Marketing, 57(1), 1-22.

55. Keller, K. L., Richey, K., 2006. The importance of corporate brand personality traits to a successful 21st century business", Brand Management, 14(1/2), 74-81.

56. Kiriakidou, O., Millward, L. J., 2000. Corporate identity: external reality or internal fit?, Corporate Communications: An International Journal, 5(1), 49-58.

57. LeBlanc, G. Nguyen, N., 1996. Cues used by customers evaluating corporate image in service 
firms, an empirical study in financial institutions, International Journal of Service Industry Management, 7(2), 44-56.

58. Lehu, J. M., 2007. Branded Entertainment, Product Placement and Brand Strategy in the Entertainment Business, Kogan Page, London.

59. Lindgreen, A., Swaen, V., 2010. Corporate Social Responsibility, International Journal of Management Review, Vol. 12.

60. Loonam, M., O'Loughlin, D., 2006. Financial e-service quality - a study of Irish online banking. Proceedings of the 35th European marketing academy (EMAC), Athens University of Economics and Business, Greece.

61. Madrigal, R., 2000. The role of corporate associations in new product evaluation, Advances in Consumer Research, 27, 80-6.

62. Maignan, I., Ralston, D.A., 2002. Corporate social responsibility in Europe and the US: insights from businesses' self-presentations, Journal of International Business Studies, 33, 497-514.

63. Mandel, L., Lachman, R., Orgler, Y., 1981. Interpreting the image of banking, Journal of Bank Research, 11, 96-104.

64. Mastura, A., Wahab, Ali Quazi, Blackman, D., 2016. Measuring and validating Islamic work value constructs: An empirical exploration using Malaysian samples, Journal of Business Research, 69, 1175-1181. http://dx.doi.org/10.1016/j.jbusres.2016.03.005.

65. Mitchel, Olson J. C., 1981. Are Product Attribute Beliefs the Only Mediators of Advertising Effects on Brand Attitudes?, Journal of Marketing Research, 18(3), 318-322.

66. Mansor, F., Bhatti, M.I., Ariff, M., 2015. New Evidence on the Impact of fees on Mutual Fund Performance of Two types of Funds, Journal of International Financial Markets, Institutions \& Money, 35, 105-115.

67. Nguyen, N., LeBlanc, G., 1998. The mediating role of corporate image on customers' retention decisions: an investigation in financial services, International Journal of Bank Marketing, 16(2), 52-65.

68. O'Cass, A., Grace, D., 2003. An exploratory perspective of service brand associations, Journal of Services Marketing, 17(5), 452-75.

69. O'Loughlin, D., Szmigin, I., 2005. Customer perspectives on the role and importance of branding in Irish retail financial services, International Journal of Bank Marketing, 23(1), 827.

70. Parasuraman, A., Zeithaml, V. A., Berry, L. L., 1988. Servqual: A multiple-item scale for measuring consumer perceptions, Journal of Retailing, 64(1), 12-40.

71. Park, C.W., Jaworski, B.J., Maclnnis, D. J. (1986), "Strategic brand concept-image management", Journal of Marketing, 50, 135-45.

72. Pina, J. M., Martinez, E., De Chernatony, L., Drury, S., 2006. The Effect of Service Brand Extensions on Corporate Image. An Empirical Model, European Journal of Marketing, 40(1/2), 174-197.

73. Ratnasingham, P., 1998. The importance of trust in electronic commerce, Internet research, 8(4), 313-321.

74. Richardson, B.A., Robinson, C.G., 1986. The impact of internal marketing on consumer service in a retail bank, International Journal of Bank Marketing, 4(5), 3-30.

75. Rui Vinhas Da Silva, Sharifah Faridah Syed Alwi, 2006. Cognitive, affective attributes and conative, behavioural responses in retail corporate branding, Journal of Product and Brand Management, 15(5), 293 - 305.

76. Shimp T. A., 2010. Integrated Marketing Communication in Advertisement and Promotion, $8^{\text {th }}$ Edition, South-Western, Cengage Learning.

77. Wu, S. and Lo, C. L., 2009. The influence of core-brand attitude and consumer perception on purchase intention towards extended product, Asia Pacific Journal of Marketing and Logistics, 
21(1), 174-194.

78. Snider, J., Hill, R.P., Martin, D., 2003. Corporate social responsibility in the twenty first century: a view from the world's most successful firms, Journal of Business Ethics, 48, 17587.

79. Souiden, N., Kassin, N.M., Hong, H.J., 2006. The effect of corporate branding dimensions on consumers' product evaluation. A cross-cultural analysis, European Journal of Marketing, 40(7/8), 825-845.

80. Stubbs, W., Cocklin, C., 2007. Cooperative, community-spirited and commercial: Social sustainability at Bendigo bank, Corporate Social Responsibility and Environmental Management, 14(5), 251-262.

81. Van Heerden, C.H., Puth, G., 1995. Factors that determine the corporate image of South African banking institutions: an exploratory investigation, International Journal of Bank Marketing, 13(3), 12-17.

82. Van Riel, A., Lemmink, J., Ouwersloot, H., 2001. Consumer evaluations of service brand extensions, Journal of Service Research, 3(3), 220-231.

83. Van Riel, C.B.M., 1997. Research in corporate communication: an overview of an emerging field, Management Communication Quarterly, 11(2), 288-309.

84. Virvilaite, Daubaraite U., 2011. Corporate Social Responsibility in forming corporate image, Journal of Inginerine Ekonomika Engineering Economics, 2, 534-543

85. Virvilaite, R., Saladiene, V., Zvinklyte, J., 2011. The impact of external and internal stimuli on impulsive purchasing, Economics and Management, 16, 1329-36.

86. Vlachos, P.A., Tsamakos, A., Vrechopoulos, A.P., Avramidis, P.K., 2009. Corporate social responsibility: attributions, loyalty, and the mediating role of trust, Journal of the Academy of Marketing Science, 37, 170-80.

87. Whetten, D. A. Lewis, D., Mischel, L. J., 1992. Towards an integrated model of organizational identity and member commitment, paper presented at the Annual Meeting of the Academy of Marketing, Las Vegas, NV.

88. Wilkinson, A., Balmer, J.M.T., 1996. Corporate and generic identities: Lessons from the cooperative bank, The International Journal of Bank Marketing, 14(4), 22-33.

89. Wind, Y., Saaty T. L., 1980. Marketing applications of the analytic hierarchy process, Management Science, 26(7), 641-658.

90. Worcester, R., 2009. Reflections on Corporate Reputations, Management Decision, 4, 573589.

91. Worcester, R. M., 1997. Managing the image of bank: the glue that binds, International Journal of Bank Marketing, 15(5), 146-52.

92. Yavas, U., Benkenstein, M., 2001. An assessment of SERVQUAL in Germany, Journal of International Selling and Sales Management, 7(1), 15-23.

93. Yavas, U., Benkenstein, M., Stuhldreier, U., 2004. Relationships between service quality and behavioral outcomes: A study of private bank customers in Germany, The International Journal of Bank Marketing, 22(2/3), 144-157.

94. Yavas, U., Shemwell, D. J., 1996. Bank image: Exposition and illustration of correspondence analysis, The International Journal of Bank Marketing, 14(1), 15-21.

95. Zeithaml, V.A., Berry, L.L., Parasuraman, A., 1996. The behavioral consequences of service quality, Journal of Marketing, 60(2), 31-47. 